\title{
Assessment of Mercury Contamination in the Kahayan River, Central Kalimantan, Indonesia
}

Rosana ELVINCE*, Takanobu INOUE*, Kouji TSUSHIMA*, Ryousuke TAKAYANAGI*, Ardianor**, Untung DARUNG**, Sulmin GUMIRI**, Salampak DOHONG**, Osamu NAGAFUCHI***, Tomonori KAWAKAMI**** and Toshiro YAMADA*****

* Department of Architecture and Civil Engineering, Toyohashi University of Technology, Toyohashi, 441-8580, Japan

** Faculty of Agriculture, University of Palangkaraya, 73112, Central Kalimantan, Indonesia

*** Department of Ecosystem Studies, The University of Shiga Prefecture, Hikone, Shiga,

522-8533, Japan

****Toyama Prefectural University, College of Technology, Toyama, 939-0398, Japan

*****Department of Water Supply Engineering, National Institute of Public Health, Wako, Saitama 351-0197, Japan

\begin{abstract}
From 2004 to 2007 we studied the contamination of the Kahayan and Rungan Rivers in Central Kalimantan, Indonesia, by mercury used in the processing of mined gold. Water, sediments and fish species were collected from both rivers. Total mercury concentration was determined by cold vapor atomic absorption spectrometry (CVAAS). In the Kahayan River and its tributaries, the highest total mercury concentration in water samples was $2260 \mathrm{ng} / \mathrm{l}$. In sediment samples, the concentration ranged from 0.002 to $0.095 \mathrm{ng} / \mathrm{mg}$ dry wt. In the Rungan River, the total mercury concentration in water samples ranged from 16 to $117 \mathrm{ng} / \mathrm{l}$ and in sediment samples from 0.003 to $0.253 \mathrm{ng} / \mathrm{mg}$ dry wt. The highest total mercury concentration in a water sample came from a tributary of the Kahayan River; the level was higher than Indonesia's drinking water standard for total mercury $(1000 \mathrm{ng} / \mathrm{l})$. However, total mercury concentrations in water samples from both main rivers were lower than the standard. The sediment sample mercury concentrations from both rivers were lower than the USEPA quality guideline. Total mercury concentrations in fish obtained from both rivers ranged from 0.02 to $0.48 \mathrm{ng} / \mathrm{mg}$ wet wt. Mystus nemurus had a total mercury concentration close to the USEPA guideline value for fish for human consumption.
\end{abstract}

Keywords: mercury, water, sediment, fish, river

\section{INTRODUCTION}

Mercury is found in the environment in metallic, inorganic, and organic forms. Most of the mercury in water, soils, plants, and animals is inorganic and organic mercury (primarily methyl mercury) (USEPA, 1999).

Mercury is one of the most toxic elements and is well known to have persistent, bioaccumulative, and neurotoxic effects in humans (Agusa, et al., 2005; Ulrich, et al., 2007). Inorganic mercury released into the environment from natural or anthropogenic sources is transformed to organic mercury (mainly the methylated form), which then accumulates in higher trophic animals through the food chain (Agusa, et al., 2005).

Mercury in aquatic systems is readily converted to organic methyl mercury by a process that is thought to be mediated by $\mathrm{SO}_{4}$-reducing bacteria, and surficial sediments are regarded as the primary sites of microbial methyl mercury production (Ulrich, et al., 2007). Bioaccumulation through the food chain increases the human risk of chronic methyl mercury exposure, mainly in those populations with high intakes of fish or fish products (Jewett and Duffy, 2007).

Address correspondence to Takanobu Inoue, Department of Architecture and Civil Engineering, Toyohashi University of Technology, Email: inoue@tutrp.tut.ac.jp

Received October 31, 2008, Accepted December 3, 2008 


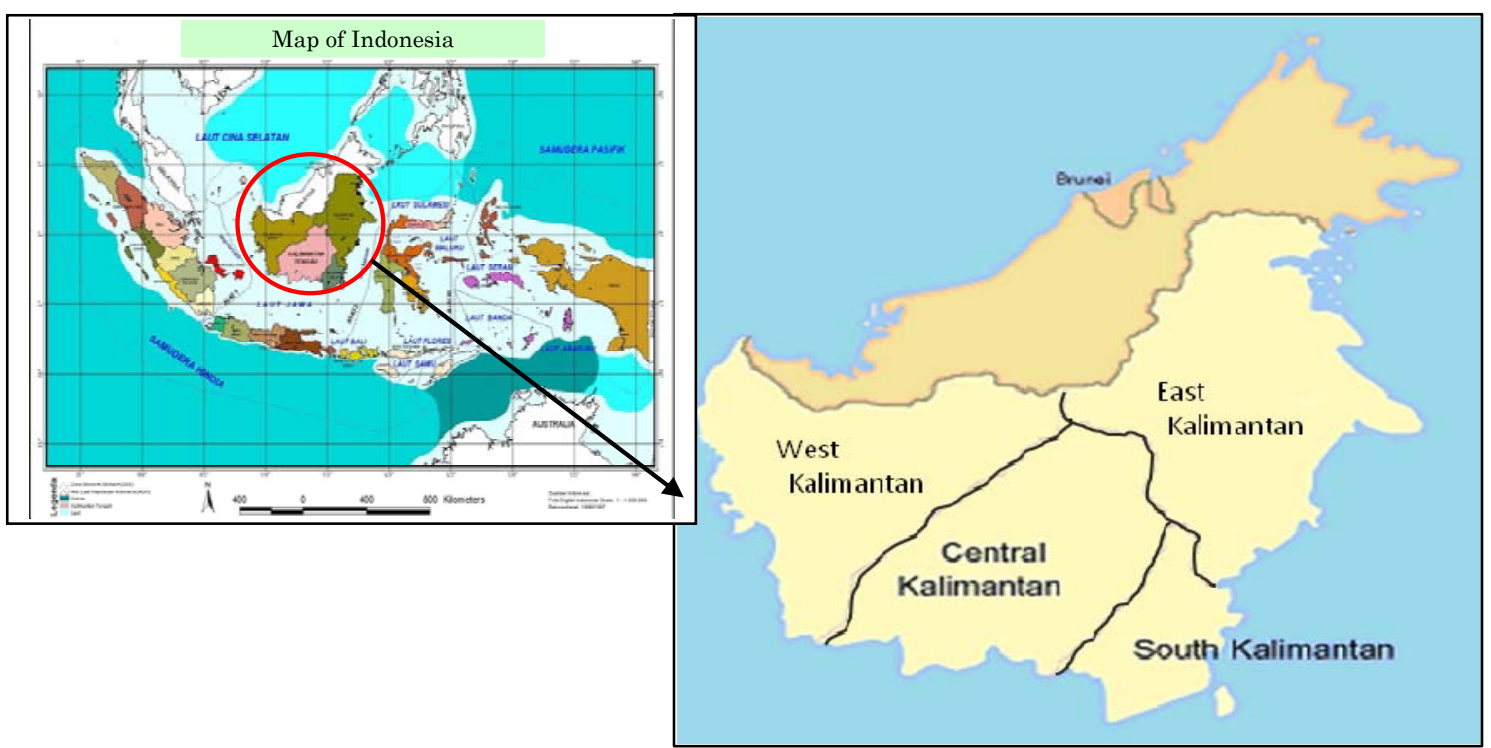

Figure 1 Location of Central Kalimantan Province

Central Kalimantan Province (capital: Palangkaraya) is located between lat. $1^{\circ} \mathrm{N}, 4^{\circ} \mathrm{S}$ and long. $111^{\circ} \mathrm{E}, 116^{\circ} \mathrm{E}$. It is bounded to the northwest by the province of West Kalimantan, to the northeast by East Kalimantan, to the southeast by South Kalimantan, and to the southwest by the Java Sea (Fig. 1).

Central Kalimantan Province has a total area of about $154,000 \mathrm{~km}^{2}$, and its population in 2006 was about 2 millions (Statistic of Central Kalimantan Province, 2006). The population density is about 12 people $/ \mathrm{km}^{2}$. The province has 11 large rivers, including the Kahayan River, and at least 33 small rivers. These rivers are used by local people for many purposes, including drinking water supply, washing, bathing, transportation, fishing, and, in recent years, gold mining. Although, importantly, gold mining contributes $19.4 \%$ to $29.1 \%$ of the annual revenue of Palangkaraya reported by Meguri, et al., 2006, however it is a major source of water pollution.

The primary pollution of the river associated with gold mining is mercury using in the gold extraction process. However, the impacts of mercury on river environments in the province are not well understood.

It is possible to elucidate the degree of pollution of aquatic environments by heavy metals (mercury) by analyzing water, sediments, and indigenous biota (i.e., biomonitors) (Kontas, 2006). In an attempt to determine the level of mercury contamination in the Kahayan and Rungan rivers, we examined total mercury concentrations in the river water, bottom sediments, and fish tissues.

\section{STUDY AREA}

The Kahayan River is a wide river in Central Kalimantan. It has four tributaries, one of which is the Rungan (about $82 \mathrm{~km}$ of long) (Statistic of Gunung Mas Regency, 2005). The Kahayan drains through the city of Palangkaraya to the Java Sea. It is $600 \mathrm{~km}$ long and has an average width of $450 \mathrm{~m}$ (Statistic of Central Kalimantan Province, 2006). 
The average water flow during the rainy season in the Kahayan River is $400 \mathrm{~m}^{3} / \mathrm{s}$ and that in the Rungan is $165 \mathrm{~m}^{3} / \mathrm{s}$. During the dry season, the respective flows are $55 \mathrm{~m}^{3} / \mathrm{s}$ and $37 \mathrm{~m}^{3} / \mathrm{s}$ (Mori, et al., 2004).

Gold mining activities are distributed over the watersheds of the Kahayan and Rungan Rivers. Commonly, these activities are conducted in the upstream villages. In 2004 a total of about 1000 units of gold mining equipment were being used in the Kahayan watershed and 200 units in the Rungan watershed (Yamada, et al., 2005).

The two rivers have been contaminated by log cutting and by soil from gold mining, both of which activities have contributed to high levels of suspended solids. The estimated total outflow of suspended solids is $5.22 \times 10^{8} \mathrm{~kg} /$ year for the Kahayan and $2.06 \times 10^{8} \mathrm{~kg} /$ year for the Rungan (Mori et al., 2004). In addition to this high output of suspended solids, gold mining activities have contaminated the rivers with elemental mercury used in the amalgamation process (Yamada, et al., 2005).

The population in the study area is estimated to be less than that of large cities such as Palangkaraya, which has a population of 160,000 (Kusuda, 2004). As well as being used for gold mining, the river basins are used for agriculture. Downstream, around Palangkaraya, water is drawn from the Kahayan by a public company to supply drinking water to the city's residents. Around Palangkaraya area fish culture is also common.

\section{MATERIALS AND METHODS}

From 2004 to 2007, we took samples at 29 stations (19 in the Kahayan River and its tributaries and 10 in the Rungan River and its one tributary). Samples were taken from the Kahayan River on three occasions between 2004 and 2007. In the Rungan River, samples were collected once from each sampling point in 2004 (Fig. 2). We collected one sample of river water and sediments from each sampling points, and seven fish species. Five of them are presented in Fig. 3. Water and sediments samples were collected from each station, however, all the fish samples were not collected at all times.

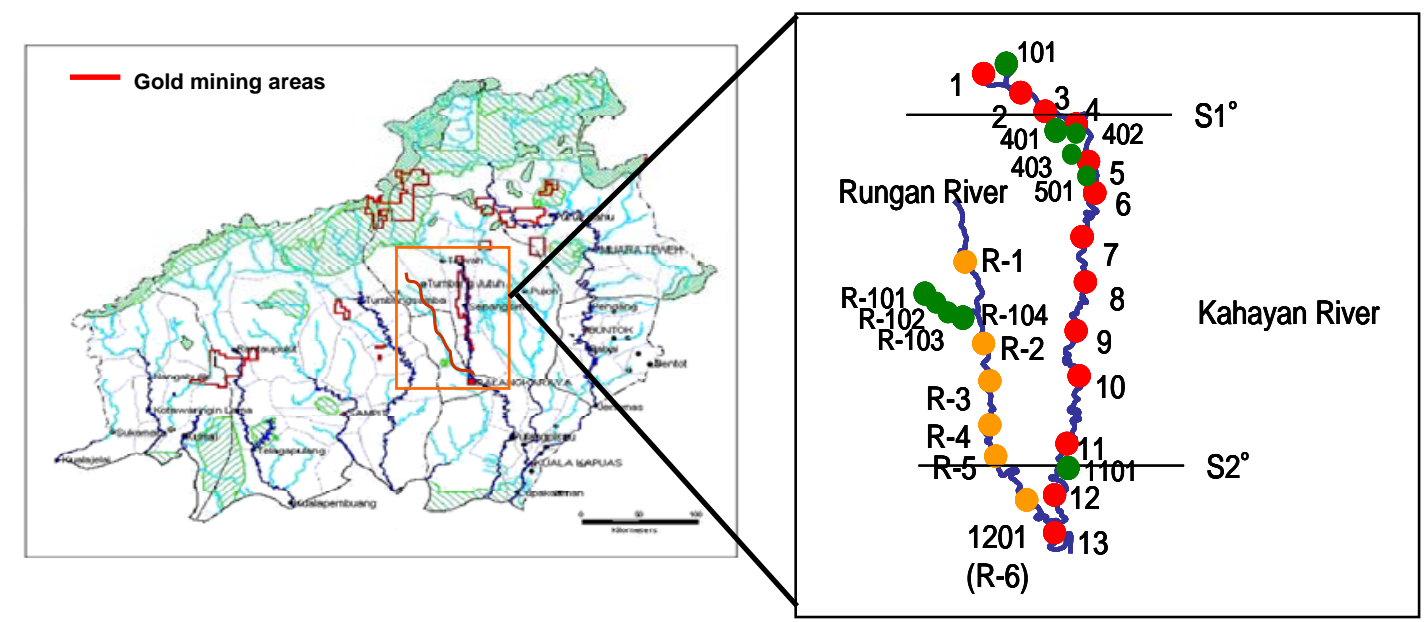

Figure 2. Map of sampling points in the Kahayan and Rungan rivers in Central Kalimantan. 

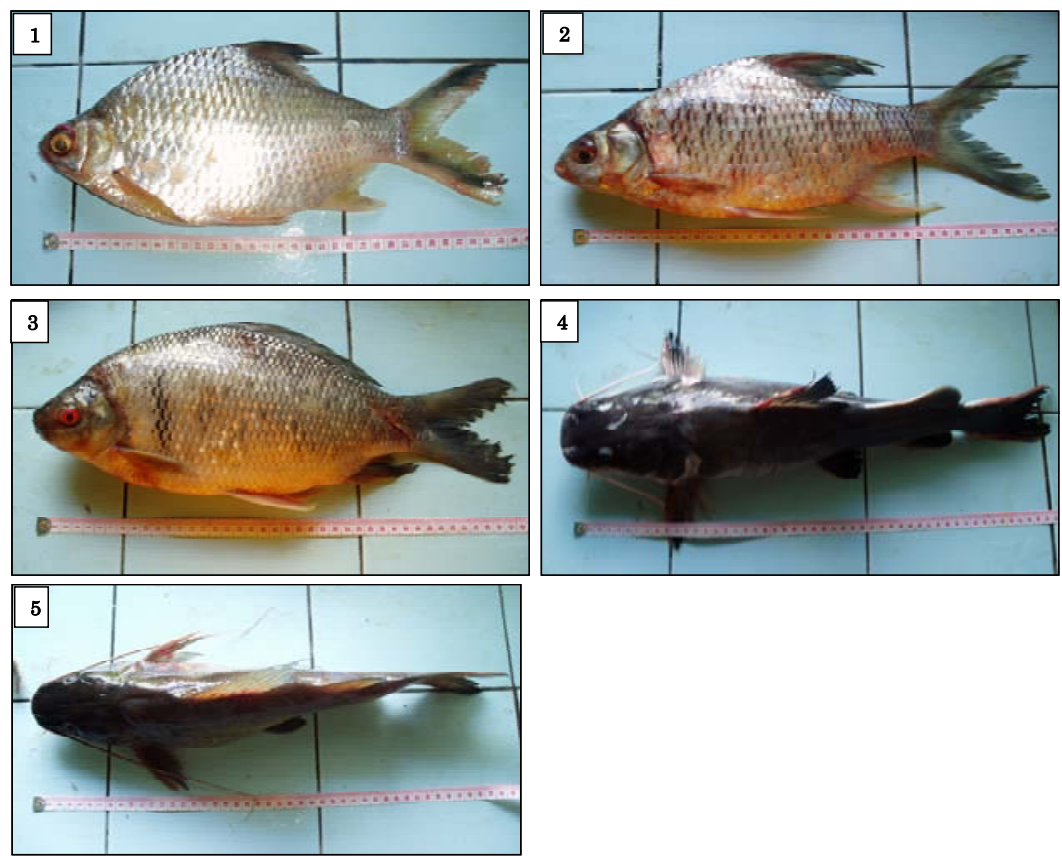

Figure 3. 1)Barbodes schwanenfeldii; 2) Barbodes gonionotus Blkr.; 3) Osteochilus melanopleurus Bl.; 4) Mystus wyckii; 5) Mystus nemurus.

Water samples were collected at the surface in 50-ml polypropylene bottles. Nitric acid was added $1 \mathrm{~mL}$ to the samples immediately after collection to decrease the $\mathrm{pH}$. Sediment samples were taken with an Ekman Grab from the riverbed at each sampling point and placed into 50-ml polypropylene bottles. All samples were kept in a refrigerator until analysis. Fish were obtained from local fishing people and measured for length and wet weight before being dissected to collect the dorsal muscle tissues for total mercury analysis.

Total mercury was extracted from sediment samples and fish species by the $\mathrm{HNO}_{3}-\mathrm{HClO}_{4}$ digestion (Ikingura and Akagi, 1999) and analyzed by cold vapor atomic absorption spectrometry (CVAAS; HG-201, Sanso Seisakusho Co., Ltd, Japan). Total mercury was extracted from water samples by the $\mathrm{KMnO}_{4}$ method in accordance with the Japanese Industrial Standard and analyzed by CVAAS (HG-200, Hiranuma). A mercury standard was made from mercury (II) chloride and checked against Hair Standard no. 13, obtained from the National Institute for Environmental Studies, Japan, to confirm the precision of the measurements.

\section{RESULTS AND DISCUSSIONS}

Mercury concentrations in water and sediment samples from the Kahayan River

Our interview with miners in 2007 revealed that they used $6 \mathrm{~g}$ of elemental mercury to obtain $1 \mathrm{~g}$ of gold. We calculated the total amount of mercury released into the environment via the rivers by using some additional data obtained from local government. 

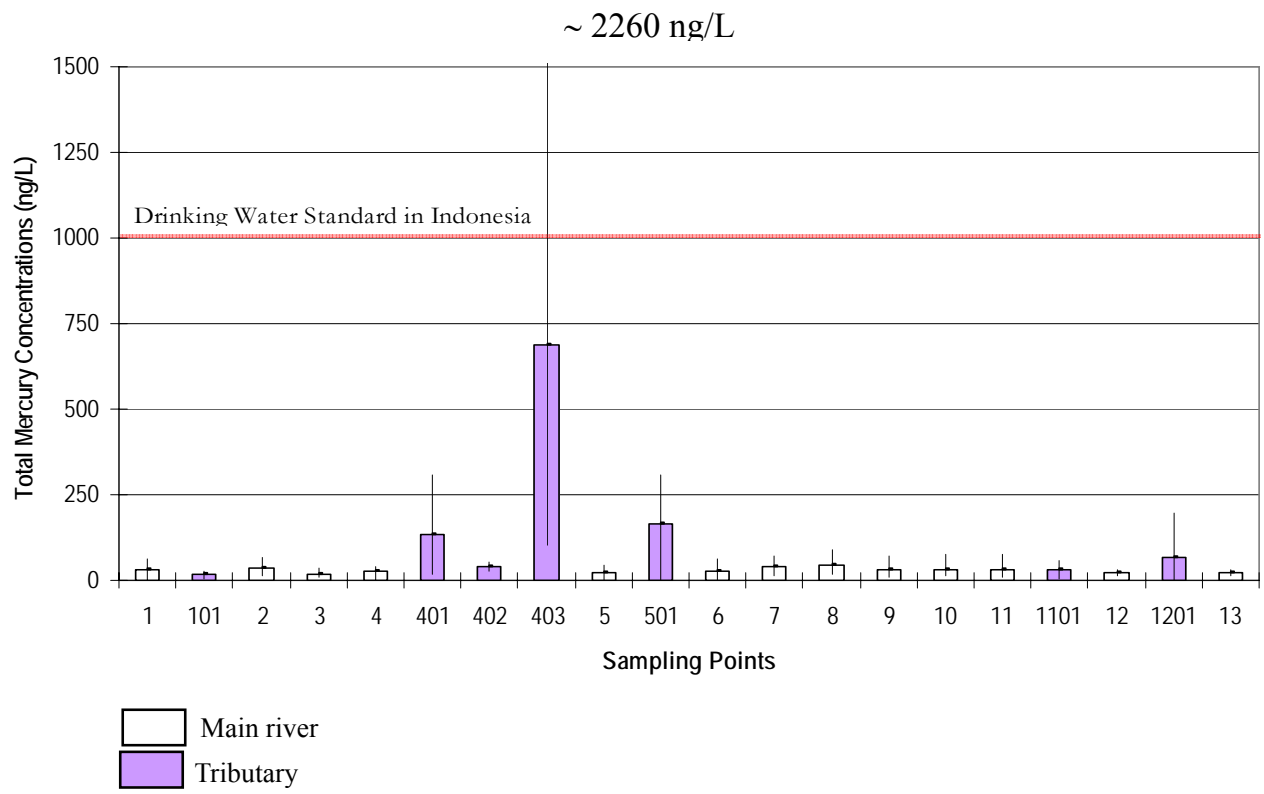

Bar columns indicated averages of mercury concentrations; Lines indicated minimum and maximum of mercury concentrations

Figure 4 Total mercury concentrations in water samples from the Kahayan River.
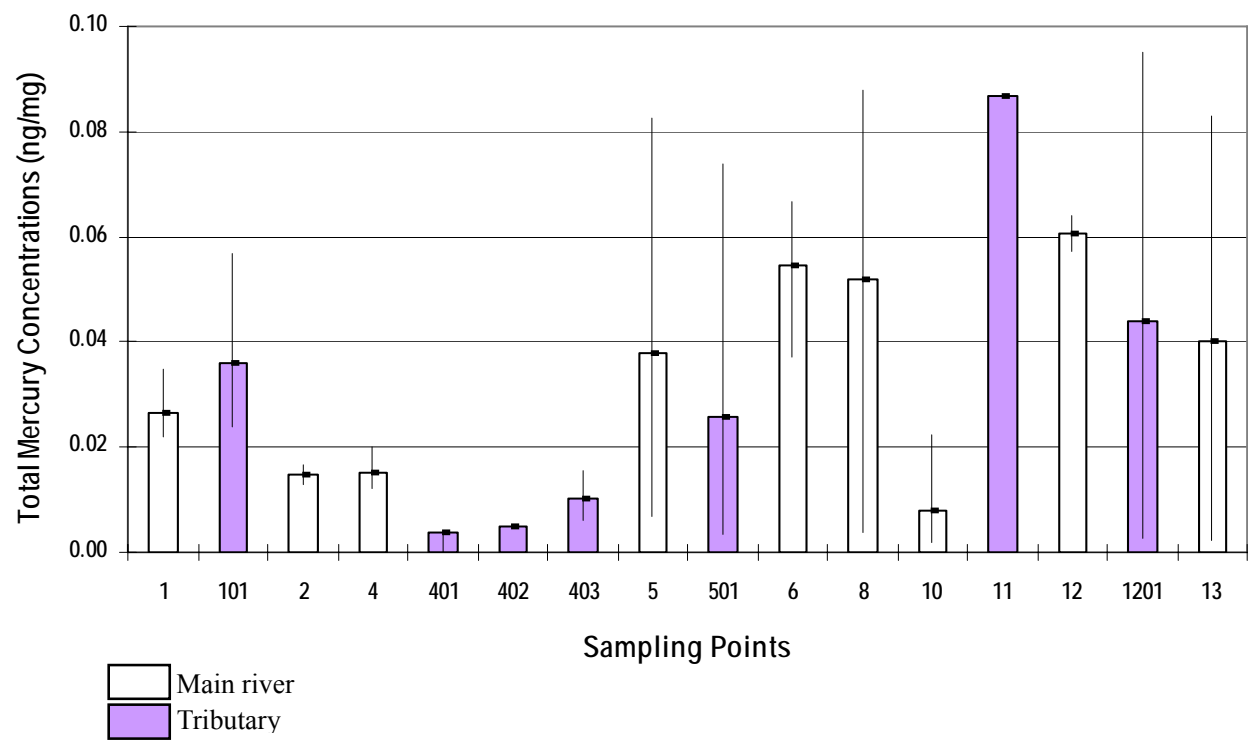

Bar columns indicated averages of mercury concentrations; Lines indicated minimum and maximum of mercury concentrations.

Figure 5. Total mercury concentrations in sediment samples from the Kahayan River

We calculated that $0.3 \mathrm{t} \mathrm{Au} /$ year was mined in the Kahayan River area by the use of approximately $1.6 \mathrm{t} \mathrm{Hg}$ /year. The values of mercury given here are based on our assumption that all mercury used for gold extraction would be released to ambient. 
Total mercury concentrations in water samples from the main river (st. 1 to 13) were no more than $88 \mathrm{ng} / \mathrm{L}$ (Fig. 4), whereas those from the tributaries (st. 101, 401, 402, 403, 501,1101 , and 1201) were up to $2260 \mathrm{ng} / \mathrm{l}$. This highest total mercury $(2260 \mathrm{ng} / 1 \mathrm{was}$ observed from its tributary at st. 403 and was higher than the Indonesian drinking water standard (1000 ng/l) (Public Health Minister of Indonesia, 2002). The highest of mercury concentrations at st. 403 is related to the location of the sampling point, where is located close to high activity of gold mining.

Total mercury concentrations in sediment samples from the main river (st. 1 to 13) ranged from 0.002 to $0.088 \mathrm{ng} / \mathrm{mg}$ dry wt., and those in samples from the tributaries (st. $101,401,402,403,501,1101$, and 1201) ranged from 0.003 to $0.095 \mathrm{ng} / \mathrm{mg}$ dry wt. (Fig. 5). The sediments in both the main river and its tributaries had total mercury concentrations lower than the USEPA quality guideline $(0.2 \mathrm{mg} / \mathrm{kg}$ ) (Donkor, et al., 2006).

\section{Mercury concentrations in water and sediment samples from the Rungan River}

We estimated the gold produced from this area in a year to be $0.43 \mathrm{t}$, and an estimated $2.57 \mathrm{t}$ of $\mathrm{Hg} /$ year was released into the Rungan River as a result of gold separation processes.

In the Rungan River and its one tributary, as a result of similar calculation to Kahayan River, the concentrations of total mercury in river water ranged from 16 to $117 \mathrm{ng} / \mathrm{L}$ (Fig. 6). These values were below the Indonesian standard for drinking water $(1000 \mathrm{ng} / \mathrm{L})$.

Total mercury in sediment samples ranged from 0.003 to $0.253 \mathrm{ng} / \mathrm{mg}$ dry wt. (Fig. 6). Total mercury concentrations in sediments from the tributary of the Rungan were higher than those in the main river, except at st. R-102, which had the lowest mercury concentration among the tributary sampling points. Mercury is deposited on suspended solids particles and can rapidly sink and settle down in river bottom sediments (Limbong, et al., 2003).

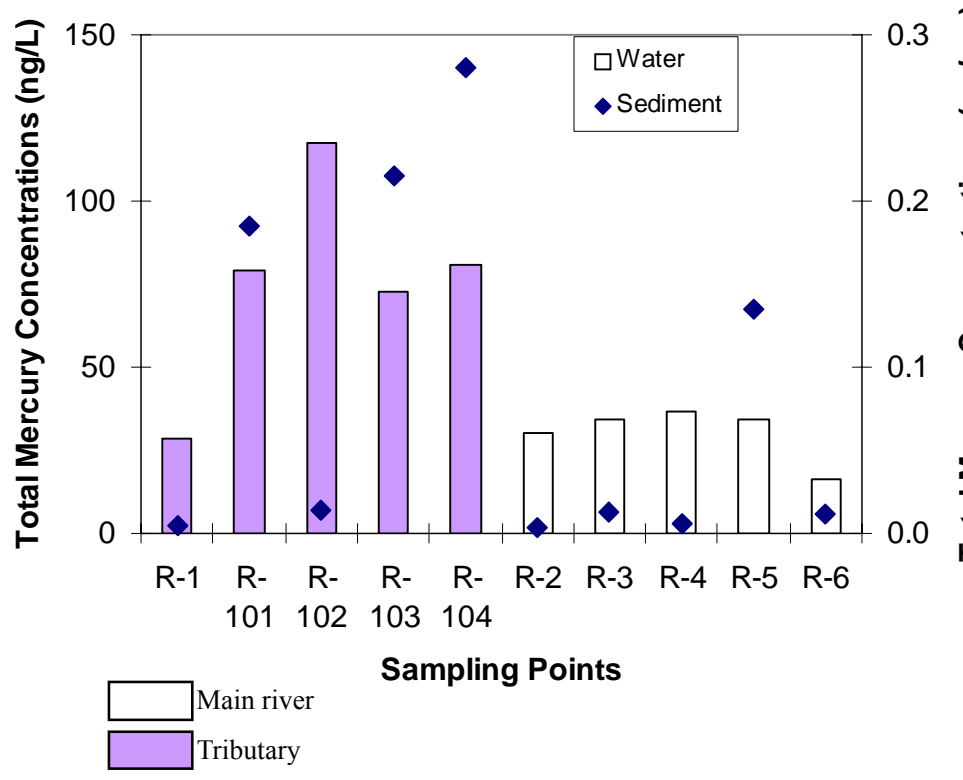

Figure 6. Total mercury concentrations in water and sediment samples from the Rungan River 


\section{Mercury concentrations in fish muscle tissues}

Fish constitutes an important source of protein for many people living in the sampling watershed. However, at the same time, levels of contaminants in fish are of considerable interest because of the potential effects on the fish themselves or the organisms that consume them, including people. Levels of contaminants, particularly methyl mercury (MeHg), are sufficiently high in some sample fish to have adverse human health effects in people consuming large quantities (Burger and Gochfeld, 2005).

Fish are used as indicators of mercury accumulation in the food chain because they can accumulate mercury in their tissues (Gochfeld, 2003). Over 75\% of the mercury accumulated in fish tissue is commonly in the organic methyl mercury compound form (Ikingura and Akagi, 2005). Methyl mercury is easily absorbed into the living tissues of aquatic organisms and is not easily eliminated For most people, exposure to methyl mercury comes from eating fish (Gochfeld, 2003).

Seven fish species were obtained from the two rivers (Table 1). Total mercury concentrations in the muscle tissues of fish taken from the Kahayan River ranged from 0.02 to $0.15 \mathrm{ng} / \mathrm{mg}$, and from the Rungan River from 0.02 to $0.48 \mathrm{ng} / \mathrm{mg}$. The carnivorous Mystus nemurus from the Rungan River had the highest total mercury concentration. The mercury level in its muscle tissues was close to the USEPA critical value for human consumption (0.3 ng/mg) (Jewett and Duffy, 2007). The M. nemurus is species that occupied high position in the food chain. The mercury is readily bioavailable and biomagnifies up the food chain so that fish at higher trophic levels regularly have mercury concentrations even highger than the water in which they live (Gochfeld, 2003; Regine, et al., 2006).

Table 1. Total mercury concentrations in fish muscle tissues

\begin{tabular}{llccc}
\hline \multirow{2}{*}{ Location } & \multicolumn{1}{c}{ Fish } & $\begin{array}{c}\text { Length } \\
(\mathbf{c m})\end{array}$ & $\begin{array}{c}\text { Weight } \\
(\mathrm{g})\end{array}$ & $\begin{array}{c}\text { Total Hg } \\
\text { (ng/mg wet) }\end{array}$ \\
\hline Kahayan River & Mystus wyckii & 51 & 1210 & 0.12 \\
& Tuyun & 38 & 330 & 0.15 \\
& Tuyun & 37 & 330 & 0.11 \\
& Mystus nemurus & 30 & 240 & 0.08 \\
& Osteochilus microcephalus & 21 & 210 & 0.02 \\
\hline \multirow{2}{*}{ Rungan River } & Osteochilus melanopleura Bl. & 40 & 1250 & 0.02 \\
& Mystus nemurus & 42 & 1040 & 0.48 \\
& Barbodes gonionotus Blkr. & 37 & 840 & 0.06 \\
& Barbodes schwanenfeldii & 34 & 740 & 0.03 \\
\hline
\end{tabular}


The concentrations of mercury in the muscle tissues of the fish obtained from the two rivers did not differ from those in the muscle tissues of fish from Lake Tilap, connected with Rungan River. (range, 0.03 to $0.43 \mathrm{ng} / \mathrm{mg}$ ). The highest mercury concentration in the fish from Lake Tilap was found in the juah (Luciosoma trinema). This is an omnivorous demersal fish that feeds mainly on insects, larvae, and zooplankton, such as cladocerans, copepods, and rotifers.

Overall, total mercury concentrations in the fishes from both rivers were below the USEPA recommendation. However, because one of the fish species had a total mercury concentration close to the USEPA standard, people living along the river should make a careful choice of fish for daily consumption. One way of minimizing the health risks associated with mercury exposure would be to decrease fish intake, and particularly the intake of $M$. nemurus.

The reported annual rate of fish consumption in Central Kalimantan is the highest of all the provinces in Indonesia. Hence there is a real risk of human mercury exposure from the diet. People who eat large amounts of fish (even species with relatively low mercury contents) can accumulate sufficient levels of methyl mercury to cause symptoms, and pregnant women can transfer methyl mercury to the fetus in amounts sufficient to impair nervous system development (Gochfeld 2003). Thus mercury contamination affects not only aquatic ecosystems but also human health (Elvince, et al., 2008).

Ecological monitoring of mercury levels in the fish of Central Kalimantan is important, since fish is a vital animal protein source for the local people. However, some fish also contain contaminants, such as mercury, that could be harmful to human health.

\section{CONCLUSIONS}

Our analysis of the total mercury concentrations in all samples (water, sediment, and fish samples) showed that the Kahayan and Rungan Rivers have been contaminated by mercury used in gold extraction. Overall, mercury concentrations in the river water were lower than the maximum limit of the Indonesian drinking water standard, except in one tributary sample. The mercury concentrations in sediments were lower than the USEPA quality guideline in both rivers. Fish tissues were contaminated by mercury but at levels lower than the USEPA guideline, although one of the species had mercury concentrations close to the USEPA standard. As sources of human mercury exposure, water, sediments and fish species in these areas should be monitored in future.

\section{ACKNOWLEGMENT}

This research was funded by a research grant from the Sumitomo Foundation.

\section{REFERENCES}

Agusa, T., Kunito, T., Iwata, H., Monirith, I., Tana, T.S., Subramaniana, A. and Tanabe, S. 2005. Mercury contamination in human hair and fish from Cambodia: levels, 
specific accumulation and risk assessment. Environ. Poll., 134, 79-86.

Burger, J. and Gochfeld, M. 2005. Heavy metals in commercial fish in New Jersey. Environ. Research, 99, 403-412.

Donkor, A.K., Bonzongo, J.C., Nartey, V.K. and Adotey, D.K. 2006. Mercury in different environmental compartments of the Pra River Basin, Ghana. Sci. of the Tot. Environ., 368: 164-176.

Elvince, R., Inoue, T., Ardianor, Darung, U., Kawakami, T., Nagafuchi, O. and Tsushima, K. 2008. Mercury contamination in Lake Tilap, Central Kalimantan, Indonesia. J. of Ecotechnol. Research., 13, 291-294.

Gochfeld M. 2003. Cases of mercury exposure, bioavailability, and absorption. Ecotoxicology and Environmental Safety, 56, 174-179.

Ikingura, J.R. and Akagi, H. 1999. Methylmercury production and distribution in aquatic systems. Sci. of the Tot. Environ., 234, 109-118.

Ikingura, J.R. and Akagi, H. 2005. Total mercury and methyl mercury levels in fish from hydroelectric reservoirs in Tanzania. Sci. of the Tot. Environ., 304, 355-368.

Jewett, S. C. and Duffy L. K. 2007. Review: Mercury in fishes of Alaska, with emphasis on subsistence species. Sci. of the Tot. Environ., 387, 3-27.

Kusuda, T. 2004. Environmental and Economic Problems in Central Kalimantan. Annual Report for April 2003 - March 2004 on Environmental Conservation and Land Use Management of Wetland Ecosystems in Southeast Asia, Core University Program between Hokkaido University, Japan, and Research Center for Biology, LIPI, Indonesia. Sponsored by Japan Society for Promotion of Science, pp. $118-124$.

Kontas, A. 2006. Mercury in the Izmir Bay: an assessment of contamination. J. of Marine Systems, 61, 67-78

Limbong, D., Kumampung, J., Rimper, J., Arai, T. and Miyazaki, N. 2003. Emissions and environmental implications of mercury from artisanal gold mining in North Sulawesi, Indonesia. Sci. of the Tot. Environ., 302, 227-236.

Meguri, M., Ujihira, M., Tachibana, H. and Nyoman, S. 2006. Study on the Present Situation of Placer Gold Mining and Improvement of Gold Processing Method in Central Kalimantan. Annual Report for April 2005 - March 2006 on Environmental Conservation and Land Use Management of Wetland Ecosystems in Southeast Asia, Core University Program between Hokkaido University, Japan, and Research Center for Biology, LIPI, Indonesia. Sponsored by Japan Society for Promotion of Science, pp. 149-153

Mori, A., Tachibana, H. and Takahashi, H. 2004. Deposition of Wash Load Observed in Kahayan and Rungan Rivers. Annual Report for April 2003 - March 2004 on Environmental Conservation and Land Use Management of Wetland Ecosystems in Southeast Asia, Core University Program between Hokkaido University, Japan, and Research Center for Biology, LIPI, Indonesia. Sponsored by Japan Society for Promotion of Science, pp. 109-117.

Public Health Minister of Indonesia. 2002. Regulation of Indonesian Public Health Ministry No. 907/Menkes/SK/VII/2002 on Conditions and Control of Drinking Water (Appendix I: Drinking Water Quality Conditions). Health Ministry of Indonesia (in Indonesian).

Regine, MB., Gilles, D., Yannick, D., Alain, B. 2006. Mercury distribution in fish organs and food regimes: significant relationships from twelve species collected in French Guaiana (Amazonian basin). Sci. of the Tot. Environ., 368, 262-270. 
Statistic of Gunung Mas Regency. 2005. Gunung Mas Regency in figures (in Indonesia)

Statistic of Central Kalimantan Province. 2006. Central Kalimantan in figures 2006/2007(in Indonesia)

Ullrich, S. M., Ilyushchenko, M.A., Uskov, G. A. and Tanton, T.W. 2007. Mercury distribution and transport in a contaminated river system in Kazakhstan and associated impacts on aquatic biota. Applied Geochemistry, 22, 2706-2734.

USEPA 1999. Mercury Update: Impact on Fish Advisories. EPA-823-F-99-016. United States Environment Protection Agency, Washington DC. http://fn.cfs.purdue.edu/anglingindiana/HealthRisks/MercuryUpdate.pdf.

Yamada, T., Inoue, T., Dohong, S. and Darung U. 2005. Mercury Contamination in River Water and Sediment in Central Kalimantan, Indonesia. Annual Report for April 2004 - March 2005 on Environmental Conservation and Land Use Management of Wetland Ecosystems in Southeast Asia, Core University Program between Hokkaido University, Japan, and Research Center for Biology, LIPI, Indonesia. Sponsored by Japan Society for Promotion of Science, pp. 115-120. 